\title{
РОЗРОБКА МЕТОДИКИ КІЛЬКІСНОГО ВИЗНАЧЕННЯ ДЛЯ ПОСТАДІЙНОГО КОНТРОЛЮ ВИРОБНИЦТВА ТАБЛЕТОК «ГІПЕРТРИЛ»
}

\author{
СЛ. І. Кучеренко, Н. В. Парнюк, З. Б. Моряк \\ Запорізький державний медичний університет \\ НВО «Фарматрон», Запоріжжя
}

\begin{abstract}
Резюме: погіршення здоров'я населення України найчастіше зумовлене серцево-судинними захворюваннями. Велику увагу приділяють розробці нових лікарських засобів для лікування цих захворювань, а також контролю їх якості. Більшість препаратів для лікування серцево-судинних захворювань застосовують у вигляді таблеток. Тому для нового лікарського засобу «Гіпертрил» обрано раціональну лікарську форму - таблетки. Відомо, що при виробництві таблеток велику увагу приділяють постадійному контролю якості. Метою нашого дослідження стала розробка методів стандартизації гіпертрилу в таблетковій масі методом спектрофотометрії. В ході роботи було досліджено 6 серій таблеткової маси гіпертрилу. Таким чином, встановлено, що всі серії за вмістом діючої речовини відповідають вимогам Державної Фармакопеї України. В результаті досліджень розробили чутливий, об'єктивний, надійний, відтворюваний метод спектрофотометричного визначення гіпертрилу у таблетковій масі.
\end{abstract}

Ключові слова: гіпертрил, таблеткова маса, таблетки, спектрофротометрія.

Вступ. Останні 20-25 років в Україні характеризуються несприятливою демографрічною ситуацією, значним зростанням захворюваності та смертності, скороченням середньої очікуваної тривалості життя. Погіршення здоров'я населення України найчастіше зумовлене серцево-судинними захворюваннями, що більш ніж на 60 \% визначають рівень загальної смертності. Артеріальну гіпертензію іноді називають «тихим вбивцею», оскільки вона часто перебігає безсимптомно, але відіграє важливу роль у розвитку різних захворювань. Підвищений артеріальний тиск $€$ основною причиною розвитку серцевих, церебральних і судинних ускладнень, зокрема ішемічної хвороби серця, хронічної серцевої недостатності, порушень мозкового кровообігу [7].

Тому розробка засобів лікування патологій серцево-судинної системи $€$ актуальною задачею сучасної медицини і фрармації. Згідно з рекомендаціями Європейського співтовариства кардіологів важливими компонентами комплексної терапії серцевої недостатності, особливо після перенесеного інфраркту міокарда, є ß-адреноблокатори, інгібітори АПФ (ангіотензинперетворювальний фрермент) та діуретики. Найбільш ефективним вважається застосування ß-адреноблокаторів останнього покоління [10].

Вищезазначене спонукало до створення принципово нового антиангінального та антигіпертензивного препарату оригінальної структури, який матиме мінімум побічних ефректів. Враховуючи важливу роль оксиду азоту (NO) в патогенезі серцево-судинних захворювань, механізм багатьох антиангінальних та антигіпертензивних препаратів розглядають через призму NO-модулюючої дії [7]. На кафедрі фрарма- цевтичної хімії Запорізького державного медичного університету в співробітництві з НВО «Фарматрон» під керівництвом професора І. А. Мазура отримано нову оригінальну сполуку - бромід 1-ß-френілетил-4аміно-1,2,4-триазолію (гіпертрил), яка проявляє антигіпертензивні, протиішемічні та антиоксидантні властивості $[1,5,6]$. Відомо, що препарати для лікування артеріальної гіпертензії в більшості випадків потрібно застосовувати протягом довготривалого часу, а іноді й усього життя. Більшість препаратів для лікування серцево-судинних захворювань застосовуються у вигляді таблеток. Тому для нового лікарського засобу обрано раціональну лікарську фрорму - таблетки.

Мета дослідження. Розробка методики кількісного визначення гіпертрилу в таблетковій масі фрізикохімічним методом.

Методи дослідження. Протягом технологічних досліджень розроблено лікарський засіб (таблетки середньою масою 0,15 г), що містить діючої речовини 0,02 г. Під час постадійного контролю виробництва таблеток найбільшу увагу приділяють контролю якості таблеткової маси [4]. Одними з найсучасніших методів фрармацевтичного аналізу є інструментальні методи, зокрема, спектральні. До переваг спектральних методів аналізу можна віднести об'єктивність, високу чутливість та точність вимірювань, селективність. Також спектральні методи характеризуються невеликою тривалістю проведення аналізу та можливістю їх автоматизації та комп'ютеризації, що значно спрощує процес аналізу [2, 3, 8, 9]. У попередніх наукових дослідженнях ми довели можливість спектрофротометричного визначення для субстанції гіпертрилу, тому наш вибір ми зупинили саме на даному методі аналізу. Також,

ISSN 2312-0967. Фармацевтичний часопис. 2015. № 2 
беручи до уваги фрізико-хімічні та фрармакотехнологічні властивості допоміжних речовин, які входять до складу таблеткової маси, припустили і надалі підтвердили, що допоміжні речовини не мають впливу на результати аналізу. Для цього в лабораторних умовах нами було виготовлено 6 серій таблеткової маси гіпертрилу із вмістом діючої речовини 0,02 г та допоміжних речовин 0,13 г у перерахунку на одну таблетку.

Вимірювання оптичної густини розчинів проводили на скануючому спектрофотометрі Optizen POP.

Результати й обговорення. Протягом попередніх досліджень ми розробили методику спектрофотометричного визначення субстанції гіпертрилу. Для цього були підібрані оптимальні умови здійснення аналізу. Концентрацію випробуваного розчину підбирали з таким розрахунком, щоб оптична густина була в оптимальному діапазоні (0,2-1). Паралельно, за тих же умов, проводили вимірювання оптичної густини робочого стандартного зразка (РС3) броміду 1- $\beta$ фенілетил-4-аміно-1,2,4-триазолію, отриманого з ДП «Завод хімічних реактивів» (м. Харків).

Результати проведених досліджень показали, що крива поглинання в УФ-ділянці Фармакопейного стандартного зразка броміду 1- $\beta$-сренілетил-4-аміно-1,2,4триазолію має три максимуми поглинання, а саме: $\lambda_{1}=252$ нм, $\lambda_{2}=258$ нм, $\lambda_{3}=263$ нм. Для аналітичних досліджень доцільно використовувати вимірювання оптичної густини при довжині хвилі 258 нм. Криву поглинання в УФ-ділянці ФСЗ броміду 1- $\beta$-оренілетил-4аміно-1,2,4-триазолію наведено на рисунку 1.

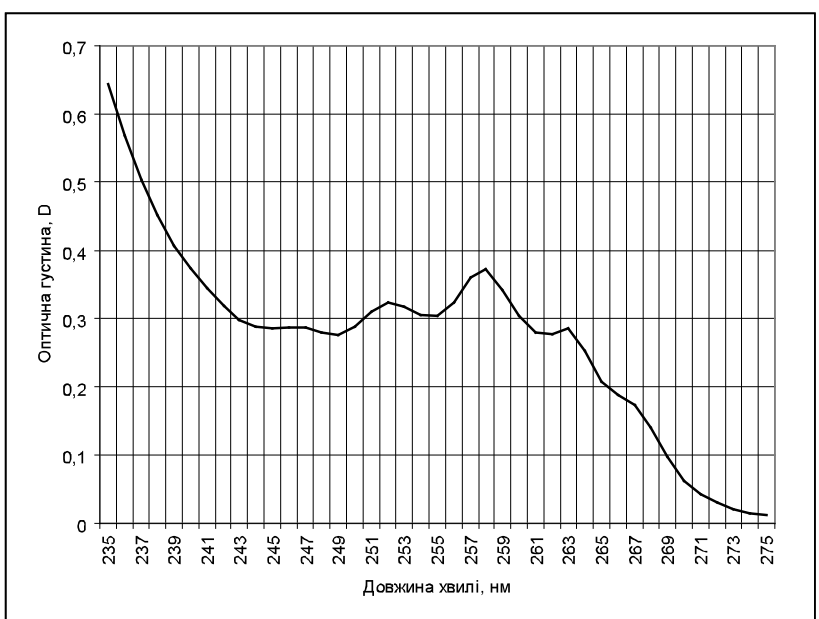

Рис. 1. УФ-спектр ФСЗ броміду 1-ß-фенілетил-4-аміно1,2,4-триазолію у воді.

Спектр поглинання в УФ-області водного вилучення з таблеткової маси гіпертрилу наведено на рисунку 2. 3 кривої поглинання видно, що максимуми поглинання таблеткової маси гіпертрилу та ФСЗ броміду 1- $\beta$-сренілетил-4-аміно-1,2,4-триазолію збігаються. Це доводить, що допоміжні речовини у складі таблеткової маси не впливають на результати аналізу.

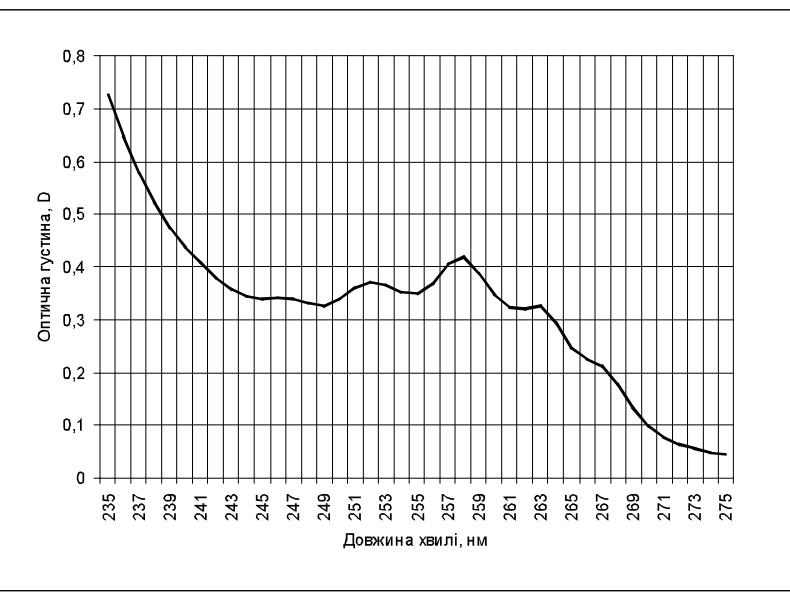

Рис. 2. УФ-спектр таблеткової маси гіпертрилу у воді.

Для кількісного визначення гіпертрилу у таблетковій масі апробували методику спектрофротометричного визначення, яку розробили та використовували для стандартизації субстанції гіпертрилу.

Методика визначення гіпертрилу у таблетковій масі методом спектрофотометрії.

Вихідний розчин. Близько 0,4 (точна наважка) таблеткової маси гіпертрилу вносять у мірну колбу на 100 мл, розчиняють у воді очищеній, доводять водою очищеною до мітки, ретельно перемішують і фрільтрують через фрільтр із діаметром пор не більше ніж 0,45 мкм.

Розчин порівняння. 0,05 г (точна наважка) робочого стандартного зразка (РС3) гіпертрилу (ДП «Завод хімічних реактивів» Науково-технологічного комплексу «Інститут монокристалів» НАН України, Україна) поміщають у мірну колбу на 100 мл, розчиняють у воді очищеній, доводять до мітки тим же розчинником, ретельно перемішують і фрільтрують через фрільтр із діаметром пор не більше ніж 0,45 мкм.

Вимірюють оптичну густину випробовуваного розчину і розчину порівняння одразу після приготування в кюветі 3 товщиною шару 10 мм при довжині хвилі $\lambda=258$ нм, застосовуючи як компенсаційний розчин воду очищену.

Вміст гіпертрилу в таблетковій масі у перерахунку на одну таблетку розраховують за фрормулою:

$$
\mathrm{X}=\frac{A_{x} \times m_{0} \times b \times \mathrm{P}}{A_{0} \times m_{x} \times 100},
$$

де $A_{x}$ - оптична густина випробовуваного розчину; $\mathrm{m}_{0}$ - наважка стандартного зразка гіпертрилу, г;

b - середня маса таблетки, г;

P - вміст гіпертрилу в стандартному зразку, \%;

$A_{0}$ - оптична густина розчину порівняння;

$\mathrm{m}_{\mathrm{x}}$ - наважка таблеткової маси, г.

Результати аналізу шести серій таблеткової маси наведено в таблиці 1.

За результатами, наведеними в таблиці 1, можна зробити висновок, що розроблена нами методика ви-

ISSN 2312-0967. Pharmaceutical review. 2015. № 2 
Аналіз лікарських препаратів

\section{Analysis of drugs}

Таблиця 1. Результати спектрофротометричного визначення гіпертрилу в модельних зразках таблеткової маси

\begin{tabular}{|c|c|c|c|c|}
\hline Серія & Маса наважки, г & Оптична густина, А & Вміст в таблетці, г & $\begin{array}{c}\text { Метрологічні характе- } \\
\text { ристики }\end{array}$ \\
\hline Таблеткова маса 1 & 0,3971 & 0,417 & 0,02046 & \multirow{7}{*}{$\begin{array}{c}X=0,0202067 \\
S^{2}=3,663^{\star} 10^{-8} \\
S=0,0001914 \\
Д X=0,0001914\end{array}$} \\
\hline Таблеткова маса 2 & 0,4052 & 0,425 & 0,02041 & \\
\hline Таблеткова маса 3 & 0,3996 & 0,414 & 0,02018 & \\
\hline Таблеткова маса 4 & 0,4001 & 0,414 & 0,02016 & \\
\hline Таблеткова маса 5 & 0,3985 & 0,409 & 0,01999 & \\
\hline Таблеткова маса 6 & 0,4004 & 0,412 & 0,02004 & \\
\hline РС3 гіпертрилу & 0,0500 & 0,385 & & \\
\hline
\end{tabular}

значення кількісного вмісту гіпертрилу в таблетковій масі методом спектрофротометрії є зручною та простою у виконанні, точною, відтворюваною та відповідає всім вимогам Державної Фармакопеї та міжнародним стандартам [3].

Висновки. В ході проведених досліджень нами розроблено методику кількісного визначення гіпер- трилу в таблетковій масі методом спектрофотометрії, яка є чутливою, об'єктивною, надійною та відтворюваною.

У подальших дослідженнях планується застосувати розроблену нами методику спектрофотометричного визначення гіпертрилу в таблетковій масі при стандартизації таблеток гіпертрилу.

\section{Література}

1. Некоторые аспекты кардиопротекторного действия нового $\beta$-адреноблокатора с NO-миметическим эфффектом «Гипертрил» на модели инфраркта миокарда I И. Ф. Беленичев, Л. И. Кучеренко, Ю. А. Волчик [и др.] // Фармакологія та лікарська токсикологія. - 2014. № 4-5 (40) - C. 11-16.

2. Георгиевский Г. В. Разработка комплекса фризикохимических методик, обеспечивающих создание и контроль качества оригинальных отечественных препаратов, производных 1,2,4-триазола / Г. В. Георгиевский // Запорожский медицинский журнал. - 2011. - Т. 13. № 1. - С. 58-69.

3. Державна Фармакопея України. - 1-е вид. Харків : Державне підприємство «Науково-експертний фрармакопейний центр», 2008. - Доповнення 2. - 2008. $-620 \mathrm{c}$.

4. Щодо постадійного контролю виробництва таблеток / Л. І. Кучеренко, О. В. Хромильова, З. Б. Моряк [та ін.] // Актуальні питання фрармацевтичної і медичної науки та практики. - 2014. - № 2. - С. 31-34.

5. Патент 2532394 Российская Федерация. МПК A61K31/4196 (2006.01) A61P9/10 (2006.01) A61P43/00 (2006.01). Применение бромида 1-(бета-оренилэтил)-4амино-1,2,4-триазолия (Гипертрил) как активной основы лекарственных средств для коррекции нарушений функционирования нитроксидергической системы органов-мишеней при гомоцистеинемии и острых

нарушения мозгового крообращения / Мазур И. А., Беленичев И. Ф., Чекман И. С. и др.; заявитель и патентообладатель ООО НПО «Фарматрон». № 2013148306. Заявл. 29.10.2013; опубл. 10.11.2014

6. Патент 84351 Україна. МПК А61K 31/41 (2006.01), А61P 9/10 (2006.01). Застосування броміду 1-( $\beta$ френілетил)-4-аміно-1,2,4-триазолію як активної основи лікарських засобів для корекції порушень функціонування нітроксидергічної системи при атеросклерозі і цукровому діабеті / Мазур І. А., Бєлєнічев І. Ф., Чекман І. С. та ін.; заявник і патентовласник ТОВ НВО «Фарматрон». - № 201212500; заявл. 02.11.2012, опубл. 25.10.2013.

7. Метаболитотропные препараты / [Мазур И. А., Чекман И. С., Беленичев И. Ф. и др.]. - Запорожье, 2007. $-304 \mathrm{c}$.

8. European Pharmacopoeia. - 6th-ed. Council of Europe. - Strasbourg, 2007. - 3857

9. Sevgi T. U. Spectrophotometric method for the determination, validation, spectroscopic and thermal analysis of diphenhydramine in pharmaceutical preparation / T. U. Sevgi, T. E. Fikriye // Spectrochimica Acta Part A: Molecular and Biomolecular Spectroscopy. - 2010. - Vol. 77. - P. 324-329.

10. White W. Blood pressure monitoring in cardiovascular medicine and therapeutscs / White W. - New Jersey: Humana Press, 2011. - 308 p. 


\title{
РАЗРАБОТКА МЕТОДИКИ КОЛИЧЕСТВЕННОГО ОПРЕДЕЛЕНИЯ ДЛЯ ПОСТАДИЙНОГО КОНТРОЛЯ ПРОИЗВОДСТВА ТАБЛЕТОК «ГИПЕРТРИЛ»
}

\author{
Л. И. Кучеренко, Н. В. Парнюк, З. Б. Моряк \\ Запорожский государственный медицинский университет \\ НПО «Фарматрон», Запорожье
}

\begin{abstract}
Резюме: ухудшение здоровья населения Украины чаще всего обусловлено сердечно-сосудистыми заболеваниями. Большое внимание уделяется разработке новых лекарственных средств для лечения этих заболеваний, а также их контролю качества. Большинство препаратов для лечения сердечно-сосудистых заболеваний применяются в виде таблеток. Поэтому для нового лекарственного средства «Гипертрил» выбрана рациональная лекарственная форма - таблетки. Известно, что при производстве таблеток большое внимание уделяют постадийному контролю качества. Поэтому целью нашего исследования стала разработка методов стандартизации гипертрила в таблеточной массе методом спектрофотометрии. В ходе работы было исследовано 6 серий таблеточной массы гипертрила. Таким образом, установлено, что все серии по содержанию действующего вещества соответствуют требованиям Государственной Фармакопеи Украины. В результате исследований разработали чувствительный, объективный, надежный, воспроизводимый метод спектрофотометрического определения гипертрила в таблеточной массе.
\end{abstract}

Ключевые слова: гипертрил, таблеточная масса, таблетки, спектрофотометрия.

\section{DEVELOPMENT OF QUANTITATIVE DETERMINATION METHODS FOR THE STEPWISE CONTROL OF «HYPERTRIL» TABLETS PRODUCTION}

\section{I. Kucherenko, N. V. Parnyuk, Z. B. Moryak \\ Zaporizhian State Medical University Scientific Production Association "Pharmatron"}

Summary: the deterioration of Ukrainian population health is often caused by cardiovascular diseases. Much attention is paid to the development of new drugs to treat these diseases and to their quality control. Most drugs for the treatment of cardiovascular diseases are used in the form of tablets. Therefore, rational dosage form - tablet - is chosen for new drug "Hypertril". It is known that stepwise quality control is paid great attention in the manufacture of tablets. Therefore, the aim of our study was the development of methods of standardization of hypertril in the tablet mass by spectrophotometry. During the work 6 series of hypertril tablet mass were studied. We established that all series meet the requirements of the State Pharmacopoeia of Ukraine concerning the contents of active substance. Our research resulted in the development of a sensitive, objective, reliable and reproducible method of the spectrophotometric determination of hypertril in the tablet mass.

Key words: hypertril, tablet mass, tablets, spectrophotometry.

Отримано 02.04.2015

ISSN 2312-0967. Pharmaceutical review. 2015. № 2 